GRASAS Y ACEITES 70 (2)

April-June 2019, e300

ISSN-L: 0017-3495

https://doi.org/10.3989/gya.0583181

\title{
The effect of cold storage, time and the population of Pseudomonas species on milk lipolysis
}

\author{
F.A.B. Pereira ${ }^{a}$, L.L. Luiz ${ }^{a}$, S.R. Bruzaroski ${ }^{a}$, R.C. Poli-Frederico ${ }^{b}$, R. Fagnani ${ }^{a}$ and E.H.W. Santana ${ }^{a}{ }^{凶}$ \\ ${ }^{a}$ Master's Degree in Science and Technology of Milk and Dairy Products, Universidade Norte do Parana - UNOPAR, Av. Paris, 675, \\ Zip Code 86041120, Londrina, Paraná, Brazil. \\ ${ }^{b}$ Master and PhD's Degree in Rehabilitation Science, UNOPAR. reginafrederico@yahoo.com.br \\ $\triangle$ Corresponding author: elsahws@hotmail.com
}

Submitted: 29 May 2018; Accepted: 02 October 2018; Published online: 12 February 2019

\begin{abstract}
SUMMARY: The aim of this study was to evaluate the lipolytic index (LI) of Pseudomonas fluorescens and Pseudomonas putida $(2,5,6 \log \mathrm{CFU} / \mathrm{mL})$ in milk during $96 \mathrm{~h}$ by the Lipo R method. The strains were isolated from refrigerated raw milk $\left(30^{\circ} \mathrm{C}, 48 \mathrm{~h}\right)$, and species were confirmed by PCR, inoculated in reconstituted whole milk, and stored at $2{ }^{\circ} \mathrm{C}, 4{ }^{\circ} \mathrm{C}$, and $8{ }^{\circ} \mathrm{C}$. The storage time (ST) and temperature were associated with LI of P. putida. The interaction among lipolysis, temperature, and ST occurs even with a low population of $P$. putida and these variables combined together contributed to about $77 \%$ of the free fatty acids (FFA) in milk. The ST, temperature, and population of $P$. fluorescens showed a significant effect on its LI, and the variables contributed to about $43 \%$ of FFA. LI was about $224 \%$ higher in milk with $P$. fluorescens than with $P$. putida. The reduction in ST and milk temperature resulted in a decrease in lipid lysis and a lower index of FFA by $P$. putida and $P$. fluorescens, with $P$. fluorescens showing a higher lipolytic capacity.
\end{abstract}

KEYWORDS: Enzymatic activity; Lipase; Milk lipolysis; Pseudomonas fluorescens; Pseudomonas putida

RESUMEN: Efecto del almacenamiento en frío, el tiempo y la población de especies de Pseudomonas sobre la lipolisis de la leche. El objetivo fue evaluar el índice lipolítico (LI) (por el método Lipo R) de Pseudomonas fluorescens y Pseudomonas putidas (2, 5, $6 \log \mathrm{CFU} / \mathrm{mL}$ ) en leche durante $96 \mathrm{~h}$. Las cepas se aislaron de leche cruda refrigerada $\left(30^{\circ} \mathrm{C}, 48 \mathrm{~h}\right)$, las especies se confirmaron por PCR, se inocularon en leche entera reconstituida y se almacenaron a 2,4 y $8{ }^{\circ} \mathrm{C}$. El tiempo de almacenamiento (ST) y la temperatura se asociaron con LI de $P$. putida. La interacción entre lipólisis, temperatura y ST ocurre incluso con una población baja de $P$. putida y estas variables combinadas contribuyeron a aproximadamente el $77 \%$ de los ácidos grasos libres (FFA) en la leche. El ST, la temperatura y la población de P. fluorescens mostraron un efecto significativo en su LI, y las variables contribuyeron a aproximadamente el $43 \%$ de FFA. LI fue aproximadamente un $224 \%$ mayor en leche con $P$. fluorescens que con $P$. putida. La reducción de la temperatura de ST y de la leche dio como resultado una disminución en la lisis lipídica y un índice más bajo de FFA por $P$. putida y $P$. fluorescens, esta última mostrando una mayor capacidad lipolítica.

PALABRAS CLAVE: Actividad enzimática; Lipasa; Lipólisis de la leche; Pseudomonas fluorescens; Pseudomonas putida

ORCID ID: Pereira FAB https://orcid.org/0000-0002-8826-1891, Luiz LL https://orcid.org/0000-0002-5364-5131, Bruzaroski SR https://orcid.org/0000-0001-5574-331X, Poli-Frederico RC https://orcid.org/0000-0003-4631-4606, Fagnani R https://orcid.org/0000-0002-7392-2087, Santana EHW https://orcid.org/0000-0002-7789-2575

Citation/Cómo citar este artículo: Pereira FAB, Luiz LL, Bruzaroski SR, Poli-Frederico RC, Fagnani R, Santana EHW. 2019. The effect of cold storage, time and the population of Pseudomonas species on milk lipolysis. Grasas y Aceites 70 (2), e300. https://doi.org/10.3989/gya.0583181

Copyright: (C2019 CSIC. This is an open-access article distributed under the terms of the Creative Commons Attribution 4.0 International (CC BY 4.0) License. 


\section{INTRODUCTION}

The preservation of raw milk by cold storage without adequate sanitary-hygienic measures can allow the growth of psychrotrophic micro-organisms, the major deteriorating agents in fluid milk and dairy products (Sorhaung and Stepaniak, 1997). Pseudomonas is considered the psychrotrophic predominant genus (Fagundes et al., 2006; Pinto et al., 2006; Arcuri et al., 2008; Neubeck et al., 2015; Xin et al., 2017), producing heat resistant enzymes that hydrolyze fat and milk proteinswhich cause offflavor and economic loss (Sorhaung and Stepaniak, 1997; Mu et al., 2009).

Pseudomonas fluorescens and Pseudomonas putida are species of great relevance among the psychrotrophic microorganisms and stand out due to their short generation time at $0^{\circ} \mathrm{C}$ to $7^{\circ} \mathrm{C}$ (Sorhaung and Stepaniak, 1997), and more specifically at $4{ }^{\circ} \mathrm{C}$. Therefore, they naturally become the predominant microbiota in milk stored in this temperature range (Dogan and Boor, 2003).

Lipase is a glycoprotein that can hydrolyze long and short chain triglycerides, esters, monoglycerides and phospholipids, releasing fatty acids and glycerol molecules. The breakdown of fat globules leads to an increase in the fraction of short-chain fatty acids (C-4 to C-8), giving a rancid taste and odor to dairy products. The soapy taste and odor are produced by the hydrolysis of fatty acids with higher molecular weight (C-10 to $\mathrm{C}-12)$, whereas the metallic or oxidized taste is the result of the oxidation of unsaturated fatty acids to ketones and aldehydes (Chen et al., 2003). According to Deeth and Fitz-Gerald (2006), although milk lipolytic degradation and it effects were not as intense as the proteolytic degradation, defects such as rancid, soapy, or bitter taste, as a result of lipase activity, are the first off-flavor changes that were detectable.

Therefore, the aim of this study was to evaluate the effect of cold storage, time and the Pseudomonas fluorescens and Pseudomonas putida populations on the lipolytic index of milk.

\section{MATERIALS AND METHODS}

\subsection{Materials, reagents, and milk samples}

The Pseudomonas spp. used in this study were isolated from cold raw milk samples from five dairy farms, with counts which ranged from $2.3 \times 10^{5}$ to $1.7 \times 10^{6} \mathrm{CFUmL}^{-1}$ (Almeida et al., 2017). The milk samples were stored in cooling tanks, collected under aseptic conditions, and were kept in a Styrofoam box with reusable ice packs, until analysis. For Pseudomonas spp. isolation, CFC agar-base was used $\left(30^{\circ} \mathrm{C}\right.$ for $48 \mathrm{~h}$ ) (Almeida et al., 2017) and the isolated strains were stored at $-20{ }^{\circ} \mathrm{C}$ in $\mathrm{BHI}$ broth containing $40 \%$ glycerol.
The reagents and materials used in this study are described below. (a) CFC agar-base (Himedia, Mumbai, India), Tributyrin Agar (Himedia, Mumbai, India), Brain Heart Infusion (BHI) broth (Himedia, Mumbai, India), and skimmed milk powder (Molico, Nestlé, São Paulo, Brazil) were used for the determination of $P$. fluorescens and P. putida populations. (b) For PCR, the following reagents were used: (b1) Wizard Genomic DNA Extraction Kit (Promega Corporation, Madison, USA), buffer 10X (Invitrogen, CA, USA), $\mathrm{MgCl}_{2}$ (Invitrogen, CA, USA), dNTPs set kit (Invitrogen, CA, USA), oligonucleotides PA-GS-F, PA-GS-R, 16 SPSER, 16 SPSEfluF, P734, P1455r (Invitrogen, CA, USA), GoTaq DNA polymerase (Invitrogen, CA, USA). (b2) For the positive control in PCR, ATCC 27853, ATCC 13525, and ATCC 31483 (Coleção de Culturas Tropical - Fundação André Tosello, São Paulo, Brazil) were used. (b3) Ultrapure agarose, ultrapure tris, EDTA, and Sybr Safe (Invitrogen, CA, USA) were used for electrophoresis. (c) isopropanol (Syth, Diadema, Brazil) petroleum ether (Syth, Diadema, Brazil), sulfuric acid (Syth, Diadema, Brazil), thymol blue (Sigma, Sao Paulo, Brazil), butanol (Syth, Diadema, Brazil), potassium hydroxide (Syth, Sao Paulo, Brazil) and ethanol (Syth, Diadema, Brazil) for the Lipo R methods.

\subsection{Pseudomonas spp. isolation, confirmation of $P$. fluorescens and P. putida, and lipolytic indexes}

\subsubsection{PCR}

Bacterial genomic DNA was extracted using the Wizard Genomic DNA Extraction Kit following the manufacturer's instructions. The isolated DNA was stored at $-80^{\circ} \mathrm{C}$. The extracted genetic material was subjected to PCR for the identification of the gender Pseudomonas spp. with forward PA-GS-F (5'-GACGGGTGAGTAATGCCTA-3') and reverse PA-GS-R (5'-CACTGGTGTTCCTTCCTATA-3') primers (Spilker et al., 2004), which amplified the 16S rRNA (618 bp) gene region. For the identification of the species $P$. fluorescens, the bacterial isolates were subjected to PCR reactions with oligonucleotides 16 SPSEfluF (5'-TGCATTCAAAACTGACTG-3') and 16SPSER (5'-AATCACACCGTGGTAACCG-3') (Scarpellini et al., 2004) for the 16S rRNA gene, which is characteristic of $P$. fluorescens. For the identification of $P$. putida, were followed the protocol with the oligonucleotides P734 (5'-CAA CTCGGGCGTTGGCATTCTGCT-3') and P1455r (5'-CAAGATCGCCTGGGTACGACGGTT-3') was followed, for amplifying a fragment of $744 \mathrm{bp}$ from the gyrB gene (Yamamoto and Harayama, 1995 ) which is of $P$. putida. Ultrapure water was used as the negative control and DNA from the strains P. fluorescens (ATCC 13525) and P. putida (ATCC 31483) were used as the positive control. 
All the PCR products were subjected to agarose gel $(1.5 \%)$ electrophoresis, and the gel was stained with Sybr Safe, followed by photo-documentation under ultraviolet light.

\subsubsection{Determination of P. fluorescens and P. putida populations}

From eight and six strains confirmed to be $P$. fluorescens and P. putida, respectively, one strain of each bacterium was used for the experiment. The strains stored at $-20{ }^{\circ} \mathrm{C}$ were inoculated in $200 \mathrm{~mL}$ of $12 \%$ milk reconstituted from skimmed milk powder and incubated at $21{ }^{\circ} \mathrm{C}$ for $48 \mathrm{~h}$. The lipolytic capacity of the strains was measured by surface plating on Tributyrin Agar $\left(21^{\circ} \mathrm{C}, 72 \mathrm{~h}\right)$, considering the strains which showed a transparent halo (Frank et al., 1992) as positive.

Subsequently, the number of viable cells of Pseudomonas was determined by surface plating on CFC (cefaloridine, fusidic acid, cetrimide) agar-base (Himedia, Mumbai, India), at $30^{\circ} \mathrm{C}$ for $48 \mathrm{~h}$ (Dogan and Boor, 2003). After reaching the required bacterial cell count, decimal dilutions were made in $0.85 \%$ saline solution to obtain final concentrations of $2 \log , 5 \log$, and $6 \log$ CFU/mL. Each selected dilution was immediately used to set up cultures.

\subsubsection{Inoculation with Pseudomonas and measurement of the lipolytic index}

For the research, aliquots of $200 \mathrm{~mL}$ of $12 \%$ reconstituted milk from whole milk powder (sterilized at $121^{\circ} \mathrm{C}, 15 \mathrm{~min}$ ) (Ninho, Nestlé, Brazil) were used. Separately, the milk samples were inoculated with $2 \mathrm{~mL}$ of Pseudomonas inocula previously prepared $(2,5$, and $6 \log \mathrm{CFU} / \mathrm{mL})$ and incubated at $2{ }^{\circ} \mathrm{C}, 4^{\circ} \mathrm{C}$, and $8^{\circ} \mathrm{C}$ for $96 \mathrm{~h}$. The temperature of $4{ }^{\circ} \mathrm{C}$ was selected to simulate the temperature stipulated by Brazilian regulations for raw milk storage at dairy farms. The storage of raw milk at $2{ }^{\circ} \mathrm{C}$ and 8 ${ }^{\circ} \mathrm{C}$ were determined to be common in the Brazilian dairy farm (Almeida et al., 2017) and lipolytic activity, even in the presence of a small number of psychrotrophs, was detected at these two temperatures (Wiking et al., 2003).

The levels of free fatty acids (FFA) $(\mathrm{mEq} / \mathrm{L})$ in the milk samples with Pseudomonas spp. inoculum were quantified by the Lipo R method (MAHIEU, 1984) in three steps. In an initial extraction step, milk $(4 \mathrm{~mL})$ was added to $16 \mathrm{~mL}$ of Lipo $\mathrm{R}$ reagent (441 $\mathrm{mL}$ of isopropanol, $447.75 \mathrm{~mL}$ of petroleum ether, and $11.25 \mathrm{~mL}$ of $4 \mathrm{~N}$ sulfuric acid) and $5 \mathrm{~mL}$ of distilled water into test tubes with screw threads. The tubes were shaken by inversion 15 times, followed by resting for $5 \mathrm{~min}$ and the supernatant (supernatant-1) was obtained. Then the rinsing process was carried out by transferring $8 \mathrm{~mL}$ of the supernatant-1 to test tubes, followed by the addition of $4 \mathrm{~mL}$ of rinsing solution (sulfuric acid at $0.05 \%$ in aqueous medium) and the mixture was shaken (by inversion) 15 times. After resting for $5 \mathrm{~min}$, the supernatant- 2 was obtained. Finally, $4 \mathrm{~mL}$ of the supernatant- 2 were mixed with 5 drops of thymol blue indicator $(1 \mathrm{~g}$ of thymol blue in $1.6 \mathrm{~L}$ of Butanol-2), and titrated with potassium hydroxide in an ethanolic solution $0.002 \mathrm{~N}$.

The final results were obtained using the formula:

FFA $\mathrm{mEq} / \mathrm{L}=(\mathrm{X}-\mathrm{B})$. Fc

where $\mathrm{X}$ is the volume of base required to neutralize the supernatant-2; B is the volume of supernatant-2, and $\mathrm{Fc}$ is the correction factor for potassium hydroxide.

The Pseudomonas spp. enumeration $(\mathrm{CFU} / \mathrm{mL})$ and quantification of FFA levels $(\mathrm{mEq} / \mathrm{L})$ were carried out every $24 \mathrm{~h}$ in duplicate and triplicate, respectively, and time zero was considered the negative control. Two independent experiments were carried out with each of the strains.

\subsubsection{Statistical analysis}

The influence of storage time, temperature, and Pseudomonas spp. population over the lipolytic index was assessed through a multiple regression analysis with three explanatory variables: storage timeat four levels $(24,48,72$, and $96 \mathrm{~h})$; temperature, at three levels $\left(2{ }^{\circ} \mathrm{C}, 4^{\circ} \mathrm{C}\right.$, and $\left.8{ }^{\circ} \mathrm{C}\right)$ and bacterial population, with three levels $(2,5$, and $6 \log \mathrm{CFU} / \mathrm{mL})$. A total of 72 experimental runs were conducted, since plating was performed in duplicate. The response data was plotted as a response surface to obtain a better understanding of the underlying mechanism behind the lipolytic ability of Pseudomonas. The data were analyzed using the software Statistica, release 13.2 (Quest Software Inc., California, USA).

We also accounted for the existing differences in the lipolytic index between the strains of $P$. fluorescens and P. putida. Thus, differences were evaluated by the Mann-Whitney U test and the significance level was set at $\alpha=0.05$.

\section{RESULTS AND DISCUSSION}

The storage time and temperature were positively associated $(p<0.05)$ with the lipolytic index of $P$. putida according to the multiple regression analysis. In this way, the higher the storage time and/or temperature, the higher the level of free fatty acids in milk was, although without a causal association between these variables. Enzyme production by Pseudomonas spp. strains occurred mainly at the end of the log phase of cell growth and in a suboptimal growth environment (Mahieu, 1991).

The lipolysis over storage time and incubation temperature occurred even with a low population of $P$. putida $(2 \log \mathrm{CFU} / \mathrm{mL})$, since the P. putida concentration was not statically associated $(p=0.07)$ 
with the lipolytic index. However, due to the marginally significant effect of the $P$. putida population on the lipolytic index, this variable was kept in the model. The production of enzymes such as proteases, lipases, and phospholipases by psychotropic micro-organisms is affected by temperature, oxygen availability, environmental factors, $\mathrm{pH}$, and substrate concentration, as well as the growth stage of the microorganism (Nuñez and Nuñez, 1983).

Despite the fact that storage time, temperature and P. putida population do not depend on each other to influence lipolysis, when combined, these variables contributed to about $77 \%\left(\mathrm{r}^{2}=0.77\right)$ of the free fatty acids in milk reported herein, which means that the model fits and lipolysis can be predicted by the equation presented in Figure 1.

With regards to $P$. fluorescens, it was found that the storage time $(p<0.01)$, temperature $(p<0.01)$, and $P$. fluorescens population $(p<0.01)$ showed a significant effect on its lipolytic index. Consequently, the higher the storage time, temperature, and P. fluorescens population, the higher the levels of free fatty acids in milk were, a non-causal association that highlights the importance of good practices, lower storage temperatures, and processing milk in the shortest time in order to reduce off-flavors in dairy products. The storage time was the strongest factor influencing the lipolysis, followed by temperature and finally, by population size. These variables contributed to about $43 \%\left(r^{2}=0.43\right)$ of the free fatty acids in milk, and the lipolysis by $P$. fluorescens can be predicted by the equation presented on Figure 2 . In the study on the isolation of psychrotrophic micro-organisms from refrigerated raw milk, it was observed that all the $P$. fluorescens strains had lipolytic capacity at $4{ }^{\circ} \mathrm{C}, 7{ }^{\circ} \mathrm{C}, 10^{\circ} \mathrm{C}$, and $21^{\circ} \mathrm{C}$ (Arcuri et al., 2008).

Regardless of the storage time or temperature, the lipolytic index was about $224 \%$ higher in the milk samples inoculated with $P$. fluorescens than in the samples with $P$. putida (Table 1). Research performed in the past to observe the genetic diversity and the production of extracellular enzymes (protease, lipase, and lecithinase) by Pseudomonas spp. in the samples of raw and pasteurized milk demonstrated that the majority of the isolates were P. fluorescens and P. putida. Moreover, $69 \%$ of the $P$. fluorescens strains were positive for all enzymatic activities, while the majority of $P$. putida strains $(87.5 \%)$ were negative for all activities tested (Dogan and Boor, 2003).

Kumaresan et al., (2007) evaluated the deterioration of raw milk by psychrotrophic micro-organisms and their lipolytic activities. They concluded that $50 \%$ of the panelist respondents were able to identify the rancid taste when the levels of free fatty acids were between 0.18 and $0.20 \mathrm{mEq} / \mathrm{kg}$; when it was above $0.25 \mathrm{mEq} / \mathrm{kg}$, all the respondents were able to detect rancidity. In our study, if we consider

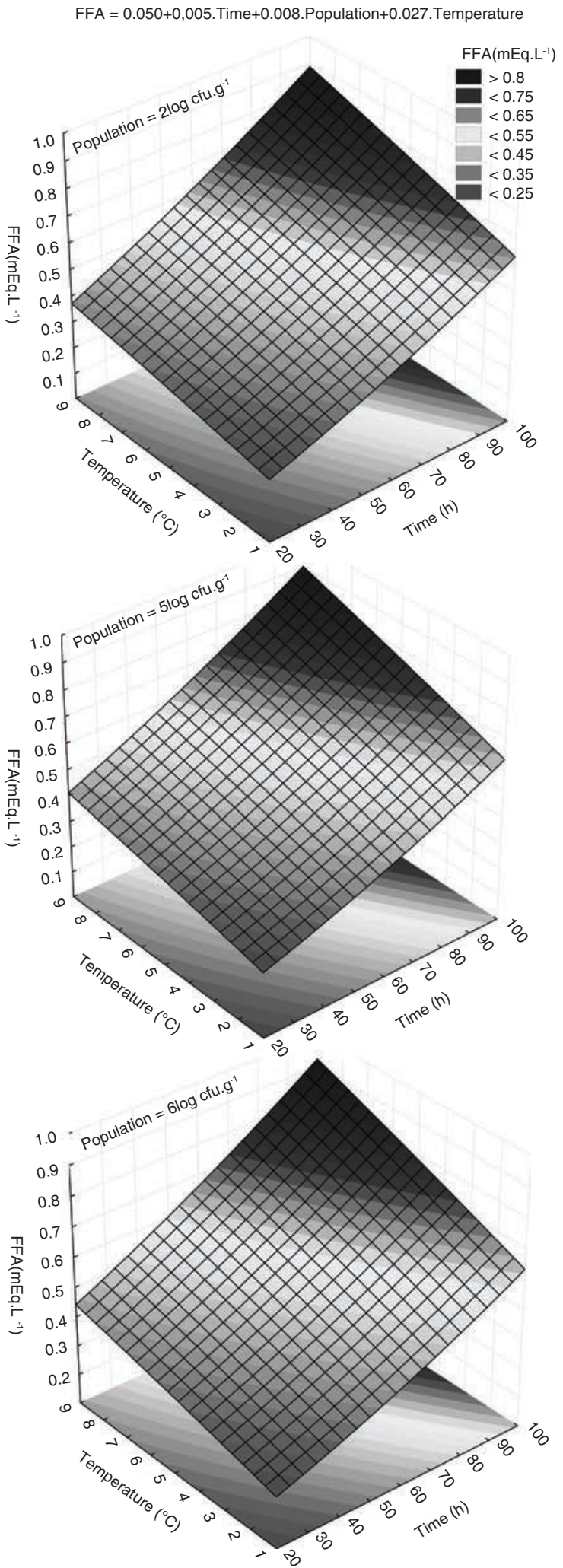

FIGURE 1. Free fatty acids in reconstituted milk $(\mathrm{mEq} / \mathrm{L})$ according to storage time, temperature and $P$. putida population*.

*According to multiple regression analysis; two replicates performed 
$\mathrm{FFA}=0.7969+0,008$.Time +0.049 .Population +0.048 . Temperature
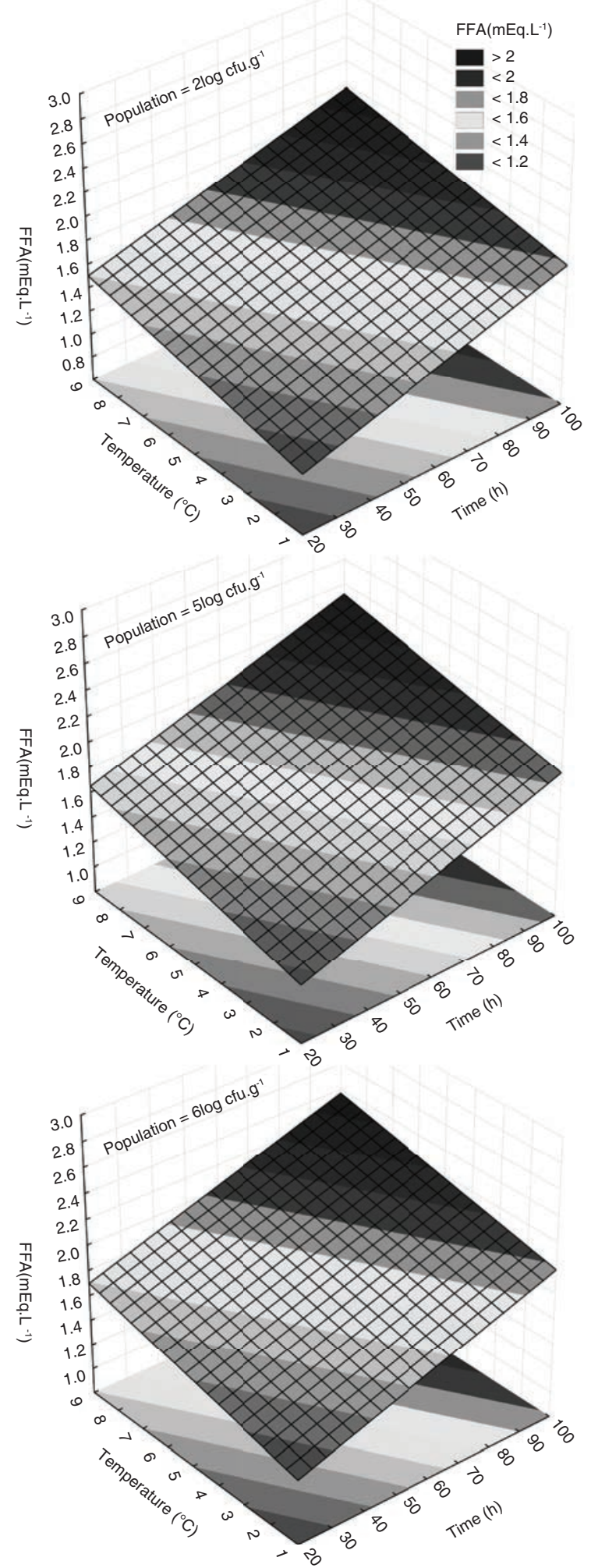

FIGURE 2. Free fatty acids in reconstituted milk $(\mathrm{mEq} / \mathrm{L})$ according to storage time, temperature and P. fluorescens population*

*According to multiple regression analysis; two replicates performed.
TABLE 1. Mean of free fat acids index (mEq/L) of reconstituted milk samples inoculated with $P$. putida or P. fluorescens, according to storage time and temperature.

\begin{tabular}{|c|c|c|c|}
\hline \multirow[b]{2}{*}{ Storage time } & \multirow[b]{2}{*}{ Temperature } & \multicolumn{2}{|c|}{ Free fat acids index $(\mathrm{mEq} / \mathrm{L}) *$} \\
\hline & & P. putida & P. fluorescens \\
\hline \multirow[t]{3}{*}{$24 \mathrm{~h}$} & $2{ }^{\circ} \mathrm{C}$ & $0.3216^{\mathrm{a}}$ & $1.4472^{\mathrm{b}}$ \\
\hline & $4^{\circ} \mathrm{C}$ & $0.3216^{\mathrm{a}}$ & $1.6080^{\mathrm{b}}$ \\
\hline & $8^{\circ} \mathrm{C}$ & $0.4288^{\mathrm{a}}$ & $1.6080^{\mathrm{b}}$ \\
\hline \multirow[t]{3}{*}{$48 \mathrm{~h}$} & $2{ }^{\circ} \mathrm{C}$ & $0.4288^{\mathrm{a}}$ & $1.5008^{\mathrm{b}}$ \\
\hline & $4^{\circ} \mathrm{C}$ & $0.4288^{\mathrm{a}}$ & $1.5544^{\mathrm{b}}$ \\
\hline & $8^{\circ} \mathrm{C}$ & $0.6432^{\mathrm{a}}$ & $1.6080^{\mathrm{b}}$ \\
\hline \multirow[t]{3}{*}{$72 \mathrm{~h}$} & $2^{\circ} \mathrm{C}$ & $0.4824^{\mathrm{a}}$ & $1.7152^{\mathrm{b}}$ \\
\hline & $4^{\circ} \mathrm{C}$ & $0.5360^{\mathrm{a}}$ & $1.8224^{\mathrm{b}}$ \\
\hline & $8^{\circ} \mathrm{C}$ & $0.6432^{\mathrm{a}}$ & $1.8224^{\mathrm{b}}$ \\
\hline \multirow[t]{3}{*}{$96 \mathrm{~h}$} & $2^{\circ} \mathrm{C}$ & $0.6432^{\mathrm{a}}$ & $1.876^{\mathrm{b}}$ \\
\hline & $4^{\circ} \mathrm{C}$ & $0.7504^{\mathrm{a}}$ & $1.9296^{\mathrm{b}}$ \\
\hline & $8^{\circ} \mathrm{C}$ & $0.8576^{\mathrm{a}}$ & $2.5192^{\mathrm{b}}$ \\
\hline
\end{tabular}

${ }^{\mathrm{a}, \mathrm{b}}$ Means followed by different letters in lines differ by the MannWhitney test $(\mathrm{P}<0.05)$; ${ }^{*}$ means of two replicates

the sensory threshold of $0.25 \mathrm{mEq} / \mathrm{kg}$ (Kumaresan et al., 2007), all milk samples with $P$. putida and P. fluorescens would have a rancid taste (Table 1), which means sensorial quality defects in milk and dairy products.

\section{CONCLUSIONS}

Lower temperature and storage time are important factors that can reduce lipid lysis in milk caused by $P$. putida and $P$. fluorescens, and avoid the effects of this enzyme in dairy products. Good cow milking to control $P$. fluorescens populations, which was more lipolytic than $P$. putida, will have a direct effect on the reduction of lipolysis in milk.

\section{REFERENCES}

Almeida KM, Bruzaroski SR, Zanol D, Melo M, Santos JS, Aragon-Alegro LC, Botaro BG, Santana EHW. 2017. Pseudomonas spp. and $P$. fluorescens: population in refrigerated raw milk. Ciênc. Rural. 47, 1-6. https://doi. org/10.1590/0103-8478cr20151540

Arcuri EF, Silva PDL, Brito MAVP, Brito JRF, Lange CC, Magalhães MMA. 2008. Counting, isolation and characterization of psychrotrophic bacteria from refrigerated raw milk. Ciênc. Rural. 38, 2250-2255. https://doi.org/10.1590/ S0103-84782008000800025

Chen L, Daniel RM, Collbera T. 2003. Detection and impact of protease and lipase activities in milk and milk powders. Int. Dairy J. 13, 255-275. https://doi.org/10.1016/ S0958-6946(02)00171-1

Deeth HC, Fitz-Gerald CH. 2006. Lipolytic enzymes and hydrolytic rancidity, in Fox P F., McSweeney PLH (Ed.). Advanced dairy chemistry: lipids. 3rd Springer: New York, p. $481-556$.

Dogan B, Boor KJ. 2003. Genetic diversity and spoilage potentials among Pseudomonas spp. isolated from fluid milk 
products and dairy processing plants. Appl. Environ. Microbiol. 69, 130-138.

Fonseca P, Moreno R, Rojo F. 2011. Growth of Pseudomonas putida at low temperature: global transcriptomic and proteomic analyses. Environ. Microbiol. Rep. 3, 329-339. https://doi.org/10.1111/j.1758-2229.2010.00229.x

Frank JF, Christen GL, Bullerman LB. 1992. Tests for groups of microorganisms, in Marshall RT (Ed) Standard methods for the examination of dairy products. American Public Health Association: New York, p. 837-856.

Kumaresan G, Annalvilli R, Sivakumar K. 2007. Psychrotrophic spoilage of raw milk at different temperatures of storage. J. Appl. Sci. Res. 3, 1383-1387.

Mahieu H. 1984. Methode rapide de dosage dês acides gras libres dans le lait: methode Lipo R. Rec. Méd. Vét. 135, 709-716.

Mahieu H. 1991. Modificaciones de la leche después de su recogida, in Luquet FM (ed) Leche y productos lácteos: la leche de la mama a la lechería, Acribia: Zaragoza. p. 181-226.

Mu Z, Du M, Bai Y. 2009. Purification and properties of a heatstable enzyme of Pseudomonas fluorescens Rm12 from raw milk. Eur. Food Res. Technol. 228, 725-734. https://doi. org/10.1007/s00217-008-0983-y

Neubeck M, Baur C, Krewinkel M, Stoeckel M, Kranz B, Stressler T, Fischer L, Hinrichs J, Scherer S, Wenning M. 2015. Biodiversity of refrigerated raw milk microbiota and their enzymatic spoilage potential. Int. J. Food Microbiol. 211, 57-65. https://doi.org/10.1016/j.ijfoodmicro.2015.07.001
Nuñez M, Nuñez JA. 1983. Proteasas de psicrotrofos gram negativos: efectos sobre la leche y los productos lácteos. Revista Española de Lechería 130, 251-260

Scarpellini M, Franzetti L, Galli A. 2004. Development of PCR assay to identify Pseudomonas fluorescens and its biotype. FEMS Microb. Lett. 236, 257-260. https://doi. org/10.1111/j.1574-6968.2004.tb09655.x

Spilker T, Coenye T, Vandame P, Lipuma JJ. 2004. PCR-Based assay for differentiation of Pseudomonas aeruginosa from other Pseudomonas species recovered from cystic fibrosis patients. J. Clin. Microb. 42, 2074-2079. https://doi. org/10.1128/JCM.42.5.2074-2079.2004

Sorhaung T, Stepaniak L. 1997. Psychrotrophs and their enzymes in milk and dairy products: quality aspects. Trends Food Sci. Technol. 8, 35-37.

Xin L, Zhaoxu M, Zhang L, Cui Y, Han X, Yi H. 2017. The diversity and proteolytic properties of psychrotrophic bacteria in raw cows' milk from North China. Int. Dairy J. 66, 34 41. https://doi.org/10.1016/j.idairyj.2016.10.014

Wiking L, Björck L, Nielsen JH. 2003. Influence of feed composition on stability of fat globules during pumping of raw milk. Int. Dairy J. 13, 799-803. https://doi.org/10.1016/ S0958-6946(03)00110-9

Yamamoto S, Harayama S. 1995. PCR amplification and direct sequencing of gyrB genes with universal primers and their application to the detection and taxonomic analysis of Pseudomonas putida strains. App. Environ. Microbiol. 61, 1104-1109. 